\title{
Measurement of Sputum Volume in Factory and Office Workers
}

\author{
D. L. MILLER, ${ }^{*} \dagger$ M.B., D.P.H. ; C. M. TINKER,* M.D., M.R.C.P. ; C. M. FLETCHER,* C.B.E., M.D., F.R.C.P.
}

Brit. med. 7., 1965, 1, 291-293

In 1959 Elmes et al. reported that it was practicable to obtain specimens of the sputum coughed up by men during the first hour in the morning before going to work, and to use the volume of these specimens to make a quantitative estimate of the severity of bronchial mucous secretion. It was found that in groups of men the mean volume of the first-hour specimen corresponded well both with answers about phlegm production and with other indices of chronic bronchitis (Fletcher et al., 1959; Fletcher and Tinker, 1961). We have been using this technique in a prospective survey designed to reveal the way in which chronic bronchitis develops in its preclinical stages among men aged 30 to 59 employed by London Transport Executive at their engineering works, and by the Post Office Savings Bank. It has been assumed that the first-hour sputum volume represents the accumulation of about eight hours' overnight secretion and bears a close relation to the total daily volume. This paper describes studies of the relation between the first-hour sputum volume and the 24-hour volume, and the variability of the first-hour volume.

\section{Relation of First-hour Volume to 24-hour Volume}

It is impracticable to ask men to expectorate all their sputum into bottles while at work in order to provide measurements of the 24-hour volume. We therefore gave 220 volunteers participating in our survey two "universal" containers and asked them to collect a 24-hour specimen of sputum throughout Sunday from the time of getting up until they went to sleep at night, and then to produce a first-hour specimen by the technique of Elmes et al. (1959) on Monday morning. Some men were asked to produce pairs of specimens of this kind on two separate occasions. It seemed possible that the volume of sputum produced on Sunday differs from that produced on other days of the week, so we repeated our observation on 23 prisoners, from whom we

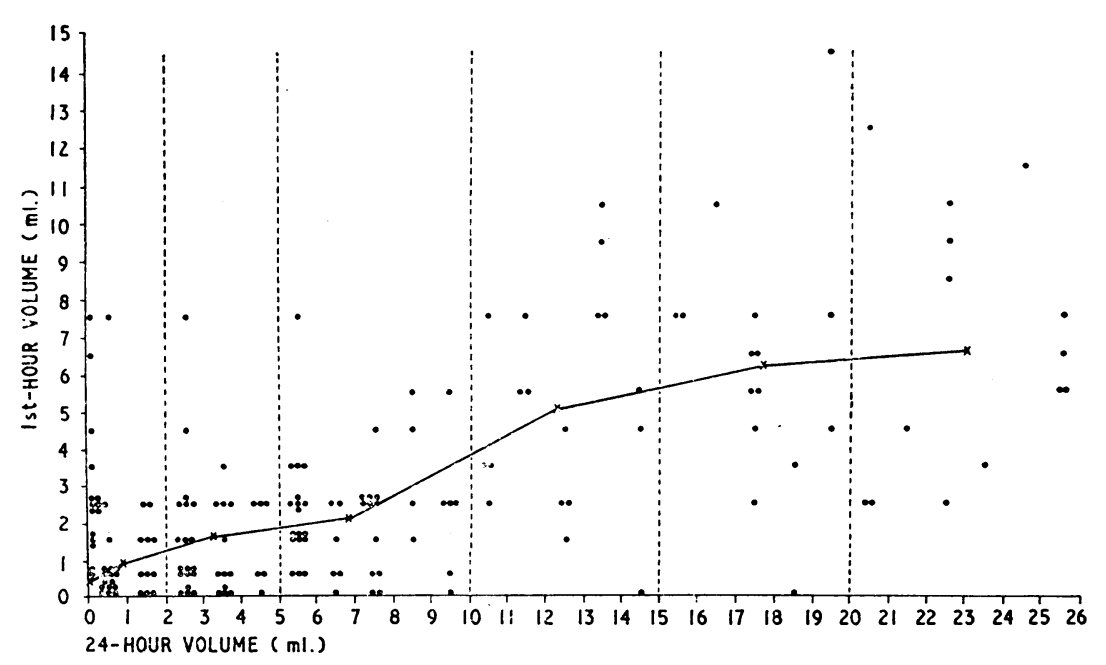

First-hour and 24-hour volumes of sputum produced by factory and office workers. 1. Each dot represents one pair of specimens. 2. The 106 pairs of bottles in which there was no sputum (see Table I) are not shown. 3. The points (X) denote the mean first-hour and 24-hour volumes for pairs of specimens within the volume ranges indicated by the vertical dotted lines. collected the first-hour specimen in one bottle and the sputum for the next 23 hours in a second bottle every day for two weeks (excluding Saturdays and Sundays). The 24-hour volume was thus measured on the same day as the first-hour volume.

The universal containers in which the sputum was collected were compared with a set of similar bottles containing known volumes of coloured water ; the volume was recorded to the nearest whole millilitre below the observed level, and $0.5 \mathrm{ml}$. was subsequently added to all values.

Table $I$ and the Chart show the relation between the first-hour and 24-hour volumes of sputum produced by the factory and office workers. In 16 of the 279 pairs of

TABLE I.-Ratio of First-hour to 24-hour Sputum Volume in Factory \begin{tabular}{c|c|c|c|c}
\multicolumn{4}{c}{ and Office Workers } \\
\hline \multirow{2}{*}{$\begin{array}{c}\text { 24-hour } \\
\text { Volume } \\
\text { (ml.) }\end{array}$} & \multicolumn{3}{|c}{279 pairs of Specimens from 220 Men } \\
\cline { 2 - 4 } & $\begin{array}{c}\text { No. of Pairs } \\
\text { Specimens }\end{array}$ & $\begin{array}{c}\text { Mean 1st-hour } \\
\text { Volume (ml.) }\end{array}$ & $\begin{array}{c}\text { Mean 24-hour } \\
\text { Volume (ml.) }\end{array}$ & $\begin{array}{c}\text { 1st-hour/ } \\
\text { 24-hour (\%) }\end{array}$ \\
\hline 0 & $122 *$ & 0.40 & 0 & -10 \\
$<2$ & 27 & 0.85 & 0.93 & 91 \\
$2-$ & 37 & 1.6 & 3.3 & 48 \\
$5-$ & 46 & 2.1 & 6.9 & 30 \\
$10-$ & 18 & 5.1 & 12.4 & 41 \\
$15-$ & 15 & 6.3 & 17.7 & 36 \\
$20+$ & 14 & 6.6 & 23.1 & 29 \\
\hline
\end{tabular}

* 16 men produced sputum on Monday morning but not on Sunday.

specimens no sputum was produced in the 24-hour period, but sputum was produced during the first hour of the next day. In 12 of these pairs the first-hour volume was less than $3 \mathrm{ml}$., but two men produced 6.5 and $7.5 \mathrm{ml}$. of sputum respectively in the first hour on Monday morning, and nothing on Sunday (see Chart). Men with 24-hour volumes of less than $2 \mathrm{ml}$. expectorated on the average more than $90 \%$ of their sputum in the first hour, whereas among those with more than $5 \mathrm{ml}$. the proportion fell to about one-third.

Among the prisoners the proportion of the 24-hour volume produced in the first hour was higher, particularly in those with large amounts of sputum (Table II). These results are based on specimens produced by a small number of men, but it may be that prisoners found it easier to use their bottles for the whole of the first hour on rising than did the men who had to hurry off to work.

Despite the wide individual variation in the proportion of the 24-hour volume produced in the first hour, the latter volume was in general greater in men who produced the larger 24-hour volumes. The first-hour volume tends to overestimate the amount of bronchial hypersecretion in those with the smaller volumes, and underestimate it in those with the larger volumes.

\footnotetext{
* From the Department of Medicine, Postgraduate Medical School, Ducane Road, London.

† Present address: Epidemiological Research Laboratory, Public Health Laboratory Service.
} 
TABIE II.--Ratio of First-hour to 24-hour Sputum Volume in Prisoners

\begin{tabular}{c|c|c|c|c}
$\begin{array}{c}\text { 24-hour } \\
\text { Volume } \\
\text { (ml.) }\end{array}$ & $\begin{array}{c}\text { 179 Pairs of Specimens from 23 Prisoners } \\
\text { No. of Pairs } \\
\text { Specimens }\end{array}$ & $\begin{array}{c}\text { Mean 1st-hour } \\
\text { Volume (ml.) }\end{array}$ & $\begin{array}{c}\text { Mean 24-hour } \\
\text { Volume (ml.) }\end{array}$ & $\begin{array}{c}\text { 1st-hour/ } \\
\text { 24-hour (\%) }\end{array}$ \\
\hline 0 & 101 & 0 & 0 & - \\
\hline $2-$ & 27 & $1 \cdot 0$ & $1 \cdot 4$ & 81 \\
$2-$ & 28 & $2 \cdot 6$ & $4 \cdot 2$ & 72 \\
$5-$ & 11 & $3 \cdot 8$ & 7.5 & 51 \\
$10+$ & 12 & $10 \cdot 2$ & $15 \cdot 4$ & 66
\end{tabular}

- 7 of the 23 prisoners produced no sputum on any occasion.

\section{Variability of First-hour Sputum Volume}

Our first investigation of the day-to-day variation of sputum volume was carried out on 71 men selected from volunteers to provide adequate representation of the range of sputum volumes. Each man was asked to produce a first-hour specimen of sputum on five days in the first and third weeks of November 1961. Fifty-six men returned their bottles with

TABle III.-Mean First-hour Sputum Volume (ml.) of $56 \mathrm{Men}$ on

\begin{tabular}{l|c|c|c|c|c|c|c} 
& & & & & \multicolumn{2}{c}{10 Days } \\
& Mon. & Tues. & Wed. & Thurs. & Fri. & $\begin{array}{c}\text { Mean } \\
\text { Volume } \\
\text { (ml.) for } \\
\text { Week }\end{array}$ & $\begin{array}{c}\text { S.E. } \\
\text { of } \\
\text { Mean }\end{array}$ \\
\hline 1st week & 2.60 & 2.47 & 2.55 & 2.69 & 2.50 & $\begin{array}{l}2.56 \\
2.17\end{array}$ & $\begin{array}{c}0.53 \\
0.46\end{array}$ \\
\hline
\end{tabular}

or without sputum every day during each of these two five-day periods. Table III shows the mean volume of each of these daily specimens. Although the mean volumes varied slightly from day to day and the volumes in the second week were consistently lower than in the first week, none of these differences are significant. Day-to-day variation in the sputum volume of individual men was, however, considerable : it was greatest in men with large volumes of sputum, as is shown in the first part of Table IV.

In a further study of 85 men between October 1962 and May 1963 (Angel et al., 1964) first-hour sputum specimens were collected at weekly intervals from each man. The extent of the considerable week-to-week variation in sputum volume of individual men is shown in the second part of Table IV.

\begin{tabular}{|c|c|c|c|c|c|}
\hline & $\begin{array}{c}\text { Range of } \\
\text { Mean } \\
\text { Volumes } \\
\text { (ml.) }\end{array}$ & $\begin{array}{l}\text { No. } \\
\text { of } \\
\text { Men }\end{array}$ & $\begin{array}{c}\text { Mean } \\
\text { Volume } \\
(\mathrm{ml} .)\end{array}$ & $\begin{array}{l}\text { Mean } \\
\text { S.D. } \\
\text { of } \\
\text { Group }\end{array}$ & $\begin{array}{l}\text { Range of } \\
\text { S.D.s } \\
\text { for } \\
\text { Individuals }\end{array}$ \\
\hline Ten daily specimens \{ & $\begin{array}{l}<2 \\
2-4 \cdot 9 \\
5-9 \cdot 9\end{array}$ & $\begin{array}{l}29 \\
17 \\
11\end{array}$ & $\begin{array}{l}0 \cdot 83 \\
3 \cdot 18 \\
6 \cdot 14\end{array}$ & $\begin{array}{l}0.89 \\
1.65 \\
2.03\end{array}$ & $\begin{array}{l}0.14-2.09 \\
0.55-2.37 \\
1.06-3.29\end{array}$ \\
\hline $\begin{array}{l}\text { Weekly specimens, } \\
\text { October to May }\end{array}$ & $\begin{array}{c}<2 \\
2-4 \cdot 9 \\
5 \text { or more }\end{array}$ & $\begin{array}{l}29 \\
21 \\
10\end{array}$ & $\begin{array}{l}0 \cdot 69 \\
3 \cdot 47 \\
9 \cdot 02\end{array}$ & $\begin{array}{l}1 \cdot 15 \\
2 \cdot 30 \\
3 \cdot 25\end{array}$ & $\begin{array}{l}0 \cdot 33-2 \cdot 40 \\
0 \cdot 81-3 \cdot 46 \\
1.66-4.27\end{array}$ \\
\hline
\end{tabular}

TABLE V.-Mean First-hour Sputum Volumes (ml.) of Factory and Office Workers in Eight Surveys

\begin{tabular}{|c|c|c|c|c|}
\hline Survey & No. of Men* & 1st Day & 2nd Day & 3rd Day \\
\hline \multirow[t]{2}{*}{$\begin{array}{l}\text { At } \\
\text { Bt }\end{array}$} & \multirow[t]{2}{*}{$\begin{array}{l}688 \\
688\end{array}$} & $\begin{array}{l}1.80 \\
1 \cdot 10\end{array}$ & $\begin{array}{l}1.67 \\
0.97\end{array}$ & $\begin{array}{l}1.44 \\
0.97\end{array}$ \\
\hline & & Tuesday & Wednesday & Thursday \\
\hline \multirow[t]{2}{*}{$\begin{array}{l}\text { C } \\
\mathbf{D} \\
\mathbf{B} \\
\mathbf{F}\end{array}$} & \multirow[t]{2}{*}{$\begin{array}{l}688 \\
793 \\
777 \\
782\end{array}$} & $\begin{array}{l}1.26 \\
1.57 \\
1.27 \\
1.16\end{array}$ & $\begin{array}{l}1.09 \\
1.49 \\
1.25 \\
1.07\end{array}$ & $\begin{array}{l}1.02 \\
1.53 \\
1.23 \\
1.05\end{array}$ \\
\hline & & 1st Week & 2nd Week & 3rd Week \\
\hline $\begin{array}{l}\mathrm{G} \neq \\
\mathrm{H} \neq\end{array}$ & $\begin{array}{l}654 \\
623\end{array}$ & $\begin{array}{l}1.39 \\
1.03\end{array}$ & $\begin{array}{l}1.27 \\
1.05\end{array}$ & $\begin{array}{l}1.19 \\
1.06\end{array}$ \\
\hline
\end{tabular}

- In each survey only men who produced three specimens are included; the 688 men in surveys $A, B$, and $C$ are the same individuals.

$t$ Specimens collected on three successive working days (i.e., excluding Saturdays

and Sundays).
Because of this variability we decided that in our follow-up study we would collect three specimens from each man on each occasion on which we wished to measure sputum volume. The results of these collections are shown in Table $\mathrm{V}$. In all but one of the surveys there was a slight decline in the mean first-hour sputum volume for the group from the first to the third collection.

We thought that this decline in volume might be due to diminishing enthusiasm over the period of collection on the part of the men, but discussion with a large number of them did not support this view, and we are at present uncertain of the significance of the phenomenon.

\section{Discussion}

Our observations on the first-hour and 24-hour volumes of sputum are complementary to those of Ashcroft (1964), since only two of his subjects expectorated less than $10 \mathrm{ml}$. in 24 hours, while the majority of our specimens were in this lower range. Above $10 \mathrm{ml}$. we found a slightly higher mean ratio of first-hour to 24-hour volume in employed men and a considerably higher ratio in prisoners than did Ashcroft. The first-hour volume gives an imperfect measure of the severity of bronchial hypersecretion. As hypersecretion increases in severity the proportion of the 24-hour volume expectorated in the first hour tends to decrease. It is also important to remember that concentration on the first-hour specimen will fail to detect the small but significant minority of subjects who do not expectorate at all on rising, but who do so later in the day.

The large day-to-day variation that we found confirms Ashcroft's observations, and shows the desirability of making repeated measurements if an individual is to be accurately categorized in terms of bronchial hypersecretion. Miller (1963) showed that there were also considerable temporal variations in sputum eosinophilia, and we have observed that specimens of sputum collected on successive days may show rapid changes in purulence. We consider, therefore, that in studies of sputum three specimens are desirable to provide a reasonable categorization of individual men. Even in large groups of subjects the mean volume may change from time to time much more than might be expected (Table V). The change in volume between the two weeks shown in Table III and the decline in volume throughout the separate three-day periods shown in Table $\mathrm{V}$ may in some instances be greater than changes in mean volume from one season to another.

\section{Summary}

Comparison of the volume of sputum expectorated by factory and office workers and by prisoners in the first hour in the morning with that expectorated by the same men throughout the day showed that as the total volume increased the proportion expectorated in the first hour decreased from over two-thirds to about one-third.

Day-to-day and week-to-week variations in first-hour sputum volume were considerable. Single specimens of sputum are inadequate to determine the customary volume of expectoration of individuals. Collection of three specimens is thought desirable to categorize both individuals and groups of men.

We wish to thank all the men who helped us in our survey for theif co-operation in the monotonous job of returning repeated sputum specimens; and also the administrative staffs of the London Transport Executive and Post Office Savings Bank and the men's representatives for their help. We are grateful to Miss Judith 
Letchner and Miss Christine Bramley for help with the analysis of the data.

\section{REFERENCES}

Angel, J. H., Fletcher, C. M., and Tinker, C. M. (1964). Awaiting publication.
Ashcroft, T. (1964). Brit. med. 7., 2, 1234.

Elmes, P. C., Dutton, A. A. C., and Fletcher, C. M. (1959). Lancet, 1, 1241.

Fletcher, C. M., Elmes, P. C., Fairbairn, A. S., and Wood, C. H. (1959). Brit. med. $7 ., 2,257$.

- and Tinker, C. M. (1961). Ibid., 1, 1491.

Miller, D. L. (1963). Amer. Rev. resp. Dis., 88, 473.

\title{
Rapid Stick Method for Determining Blood-glucose Concentration
}

\author{
VINCENT MARKS,* M.A., B.M., M.R.C.P.ED. ; A. DAWSON, † F.I.M.L.T.
}

Brit. med. F., 1965, 1, 293-294

Abnormalities of glucose metabolism are among the commonest encountered in clinical practice, and measurement of blood glucose is one of the commonest laboratory investigations. Though simple to perform, accurate measurement of the blood glucose requires both apparatus and specialized technical skill, neither of which is immediately available to the physician called urgently to see a patient in coma or to the general practitioner caring for an ambulant patient with brittle diabetes.

We describe here our experience with a new technique which requires neither special technical skill nor apparatus, and which provides a clinically useful approximation of the blood-glucose concentration within one and a half minutes.

\section{Methods and Material}

The method (Kohn, 1957) depends upon matching the colour produced when one drop of blood is added to a specially prepared enzyme-impregnated strip-Dextrostix-with the colour chart provided, corresponding with a range of blood-glucose values of between 40 and $250 \mathrm{mg}$. $/ 100 \mathrm{ml}$. (the latter now relabelled " over $200 \mathrm{mg}$. $/ 100 \mathrm{ml}$.).

Either capillary or venous blood preserved with iodoacetate (Marks and Lloyd, 1963) but not fluoride may be used. The Dextrostix is impregnated with blood, which after one minute is washed off under a stream of running tap-water for 5-10 seconds. The pale-grey to bright-blue colour revealed thereby is immediately compared with the colour chart on the bottle.

\section{Investigation Technique}

The results of blood-glucose analysis obtained by means of Dextrostix were compared with those obtained in the laboratory by means of a glucose-oxidase method (Marks and Lloyd, 1963). The Dextrostix results were recorded immediately they were made. A number of individuals, mostly laboratory technicians, but including doctors, took part in the investigation in

Blood-glucose Concentration Measured by Dextrostix. Results Obtained by Observer V.M. and by Diabetic Patients Chosen at Random from

\begin{tabular}{c|cc|c|c|c}
\hline \multirow{2}{*}{ No. } & \multirow{2}{*}{ Age and Sex } & \multicolumn{3}{|c}{ Glucose (mg./100 ml.) } \\
\cline { 3 - 6 } & & & Observer V.M. & Patient & AutoAnalyzer \\
\hline 1 & 14 & M & 200 & 200 & 239 \\
2 & 20 & F & 150 & 170 & 191 \\
3 & 77 & F & 220 & 250 & 390 \\
4 & 67 & M & 130 & 150 & 112 \\
5 & 67 & F & 130 & 250 & 136 \\
6 & 70 & M & 220 & 250 & 356 \\
7 & 57 & F & 140 & 130 & 106 \\
8 & 56 & F & 65 & 65 & 76 \\
9 & 30 & F & 170 & 150 & 170 \\
\hline
\end{tabular}

order more closely to simulate the conditions under which the technique is likely to be used. A small number of patients attending the diabetic clinic also took part (see Table).

Specimens of blood were obtained from a number of sources. Many of the patients were out-patients or were attending the diabetic clinic. Samples were taken on a number of occasions from in-patients in a psychiatric hospital. Two were receiving modified insulin therapy, on some occasions with, and on some occasions without, intravenous fructose. A patient with spontaneous hypoglycaemia was also studied.

A few samples of cerebrospinal fluid were examined by the same technique as for blood.

\section{Results}

The results of 356 individual determinations are shown in the Chart. Within the physiological range 40-200 mg./100 ml. results obtained with Dextrostix differed by less than 20 mg. $/ 100 \mathrm{ml}$. from the true value in $73 \%$ of the cases. In the remaining $27 \%$ larger errors were present-these tended to occur more often with high than with low blood-glucose levels. The errors were not consistently in one direction; overestimation of the glucose content by Dextrostix occurred slightly more often than underestimation. The percentage of large errors by different observers was similar. Nevertheless important differences were noted between different observerssome tended consistently to overestimate, others to underestimate. In the majority of cases there was no difficulty in matching, but more importance was attached to similarity of shade than intensity of the colour. Hesitation increased the chance of error, and hasty decisions were more reliable than " considered" judgments.

At blood-glucose concentrations above $200 \mathrm{mg}$. $/ 100 \mathrm{ml}$. the results obtained with Dextrostix were less reliable than in the physiological range, and the blood-glucose concentration was consistently underestimated. Nevertheless, of 50 consecutive cases in which the blood-glucose concentration exceeded 200 mg. $/ 100 \mathrm{ml}$., in only 10 was the result with Dextrostix below this figure; and in none of these did the hyperglycaemia in fact exceed $250 \mathrm{mg} . / 100 \mathrm{ml}$. In the hypoglycaemic rangethat is, blood-glucose values below $40 \mathrm{mg} . / 100 \mathrm{ml}$.- the results obtained with Dextrostix were found to be completely dependable. No case of hypoglycaemia was wrongly diagnosed.

The method was not found suitable for quantitating glucose in the cerebrospinal fluid.

* Consultant Pathologist, Department of Chemical Pathology, Epsom District Hospital, Epsom, Surrey.

+ Senior Technician, Department of Chemical Pathology, Epsom Districe Hospital, Epsom, Surrey. 